UNTAG Law Review (ULREV)

Volume 1, Issue 1, May 2017, PP 47-57

ISSN 2549-4910 (online) \& ISSN 2579-5279 (print)

http://jurnal.untagsmg.ac.id/indeks.php/ulrev/indeks

www.fakhukum.untagsmg.ac.id

\title{
PROFESSIONAL ETHICS ADVOCATES AS CONTROLLING EFFORTS IN PERFORMING LAW ENFORCEMENT FUNCTIONSAS AN ADVOCATE
}

\author{
Agus Pramono
}

Lecturer Master of Management STIE AUB Surakarta / Mediator Non Judge

\begin{abstract}
Advocate as one element of the judicial system is one of the pillars in upholding the supremacy of law and human rights. Advocates are noble professions closely related to humanity. The Advocate Profession in providing legal services and in charge of solving legal problems of his clients both in litigation and non-litigation, so he is required to always participate in the enforcement of Human Rights, and in running his profession he is free to defend anyone, not bound by orders Regardless of who the opponents of his client, whether he is from strong groups, rulers, officials and even poor people though. The Advocate function within the scope of work of the modern Advocate shows two aspects, namely 1). Represent the client before the Court; And 2). Representing clients outside the Court. Advocates as noble professions must uphold the laws and regulations of the code of ethics, so that if a violation is detrimental to the profession or the client should get the action in the form of sanctions imposed also did not eliminate the right to continue running the profession. This is where the dignity of an advocate remains respected while sanctions are a form of repression for the offenses committed.
\end{abstract}

Keywords : Professional Ethics, Law Enforcement, Advocates

\section{INTRODUCTION}

Advocate as one element of the judicial system is one of the pillars in upholding the supremacy of law and human rights. Advocates are noble professions closely related to humanity ${ }^{1}$. Therefore this advocate is a group of professions relating to the field of law. The legal profession bearers work professionally and functionally, in addition must have the level of accuracy, caution, perseverance, critical, and high dedication because they are responsible to themselves, to the community, even to God Almighty, and capable Working in accordance with the code of ethics of his profession ${ }^{2}$.

The Advocate Profession in providing legal services and in charge of solving legal problems of his clients both litigation and nonliteracy, According to Frans Hendra Winata, the task of advocate is to devote himself to the community so he is required to always participate in the enforcement of Human Rights, and in running his profession he is free to Defend anyone, not

1 Munir Fuady, Profesi Mulia (Etika Profesi Hukum bagi Hakim, Jaksa, Advokat, Notaris, Kurator, dan Pengurus), Citra Aditya Bakti, Bandung, 2005, h. 1.

2 Abdulkadir Muhammad, Etika Profesi Hukum, Cet. III. Citra Aditya Bakti, Bandung, 2006, h. 62. 
tied to client orders and regardless of who his client opponent is, whether he is from a strong group, a ruler, an official even a poor person ${ }^{3}$.

Advocate is a free profession (profession free (vrij beroep), which is not subject to hierarchy of office and is not subject to the orders of superiors, and only accepts orders or orders or power of the client under a free, written or unwritten agreement and subject to The code of ethics of the Advocate profession, not subject to political power, which has public obligations and responsibilities ${ }^{4}$. Code of ethics as a moral principle inherent in a profession. This means, without a code of ethics that deliberately arranged systematically and even then a profession can still run because the moral principles are actually already attached to the profession ${ }^{5}$.

This Code of Ethics of the Advocate profession is the code of ethics listed in Law Number 18 Year 2003 does not distinguish in criminal cases or cases outside the criminal. The application of code of ethics in the legal profession is very important because it is used as a form of moral endurance Advocate profession by explaining the function of the code of ethics in the society about the enforcement and application of the code of ethics. Advocates are part of law enforcement that parallels other law enforcement agencies. Law Number 18 Year 2003 on Advocates affirms that an Advocate is a legal, free and independent law enforcer guaranteed by law and regulation. The authority of the Advocate as a Law Enforcer is to provide legal assistance to his clients concerned with the legal issues faced. The authority of the Advocate is a law enforcement agency outside the government.

The authority to oversee the conduct of the Code of Advocate is the Council of Honor. Based on the provisions of Law Number 18 Year 2003 in Article 1 point (4) states that "Advocate Organizations are professional organizations established under this Law." The meaning of the Honorary Board contained in the Code of Indonesian Advocates is that the Board of Honor is an institution or A body established by a professional advocate organization that functions and is authorized to oversee the conduct of the Advocate Code of Conduct as required by the Advocate and is entitled to receive and examine complaints against an Advocate deemed to be in violation of the Advocate Code of Conduct. The Advocate's Privileges Body is a body established by an Advocate Organization that oversees, examines, and prosecutes an Advocate who violates the Code of Advocate Ethics. Based on the description in the background mentioned above, then the issue of this paper is how does the concept of supervision Advocate perform the function as law enforcement?

\section{DISCUSSION}

Advocate terminologically means a lawyer who provides help or help in legal matters ${ }^{6}$. This assistance or help is giving advice as good services, in its development can then be requested by anyone in need, need it for lawyers. Law Number 18 Year 2003 regarding Advocate in Article 1 paragraph (1) defines Advocate as a person who has a legal service profession both inside and outside the court of eligibility. Legal Services in the form of providing legal consultations, legal assistance, exercise power, represent, accompany, defend, and perform other legal actions for the client's legal interests. The Indonesian Advocate Code of Conduct

3 Hendra Winata, Frans, Advokat Indonesia, Citra, Idealisme dan Kepribadian, Sinar Harapan, Jakarta, 1995, h. 14.

4 Rapaun Rambe, Teknik Praktik Advokat, Grasindo, Jakarta, 2003, h. 37.

5 Shidarta, Moralitas Profesi Hukum, Suatu Tawaran Kerangka Berpikir, Refika Aditama, Bandung, 2006, h. 107.

6 Lasdin Wlas, 1989, Op. Cit., hlm. 2. 
defines an Advocate as a person who practices law services both inside and outside the Court that meet the requirements under applicable law, either as an Advocate, Lawyer, Legal Counsel, Lawyer of Practice or as a Legal Consultant ${ }^{7}$.

According to Luhut M.P. Pangaribuan that as regulated in Article 5 paragraph (1) of Law Number 18 Year 2003 on Advocates states that, advocates are Law Enforcement. This means that all services, actions, and even the behavior of advocates are in order or as law enforcement $^{8}$. Rusli Muhammad opinion that with the issuance of Law No. 18 of 2003 on Advocates, it is clear the position of advocates as law enforcement'. Todung Mulya Lubis also stated that "Advocates should no longer feel unequal to other law enforcers because the Advocate Law guarantees the existence of an advocate as an officer of the court as it is written in Article 5 of the Advocate Law whose responsibility is the same as enforcing the law And justice" ${ }^{10}$.

The Advocate function within the scope of work of the modern Advocate shows two aspects, namely 1). Represent the client before the Court; And 2). Representing clients outside the Court. The function of representing clients before the Court is a classic thing, whose existence has existed since the birth of the profession within the jurisdiction of the Court to represent its clients. While the function of representing clients outside the Court is an Advocacy function that develops as the complexity of public relations increases. Advocate is an honorable profession (officium mobile) and therefore gains full trust from the clients it represents. This trust relationship is expressed in the phrase "the lawyer as a fiduciary" and the "duty of fidelity" of advocates to their clients. As a result of the relationship of trust and obligation to loyal to his client, the principle of advocate obligation holds the secret of office (Article 4 paragraph $8 \mathrm{KEAI})^{11}$.

An advocate must endeavor to obtain as much and as good knowledge as possible of his client's case, before providing legal advice and assistance. He is obliged to give his opinion candidly about the merit of the case to be litigated and possible results. In canon $8 \mathrm{ABA}$ it is called "duty to give candid advice". While in the KEAI it is warned that advocates "do not ... give misleading information" and "do not ... assure to their clients that the case in hand will win" (Article 4 paragraphs 2 and 3). One of the main tasks of an advocate is to keep himself from accepting cases from clients that generate "conflicting interest" ${ }^{12}$.

The existence of an Advocate as part of a judicial system which has impunity should not only be viewed in a narrow sense that is subjective as if addressed to the client's interest but should be seen from its function in the broad sense that Advocates through legal services are also provided for justice and for the upright Law for anyone seeking justice.

7 Kode Etik Profesi Advokat Indonesia, Pasal 1.

8 Luhut M.P. Pangaribuan, Hukum Acara Pidana; Surat Resmi Advokat di Pengadilan, Papas Sinar Sinanti, Jakarta, 2013, h. 55.

9 Rusli Muhammad, Lembaga Pengadilan Indonesia Beserta Keputusan Kontroversial, UII Yogyakarta Press, Yogyakarta, 2012, h. 58.

10 Todung Mulya Lubis, Jalan Panjang Hak Asasi Manusia, PT Gramedia Pustaka Utama, Jakarta, 2005, h. 101.

11 The secret of office is somewhat mistaken, as in the professional relationship between physician and patient, the submitted and requested assistance is based on "confidential and highly personal patient information". I suggest that in the KEAI also interpret it only as "confidential information between advocates and clients".

12 Conflicts of interest between client and prospective client or between two (or more) advocate clients should be avoided. Advocates cannot represent conflicting interests and may adversely affect each other. The problem is not just a confidential client-advocate communication. As far as possible advocates should avoid situations of advocate-client relations both now and in the future have conflicts of interest. 
The function of the law is to ensure the order of a peaceful and just society, so that human interests are protected, that is why the law must be carried out and takes place normally, but the occurrence of lawlessness in a society cannot be avoided, then the law must be upheld, Basically everyone should not do legal irregularities. In foreign languages the popular Enforcement term used is Law enforcement. Its motto: fiat justitia et pereat mundus means even though the world is collapsing the law must be enforced.

In upholding the law to achieve the order of society contained three elements that must always be considered, namely legal certainty (rechtszekerheid), usefulness (nuttigheid) and justice (rechtsvaardigheid).

1. Legal certainty is a yustisiable protection against the arbitrary acts of law enforcement officers or any party, because with the certainty of public law will be orderly and guarantee clarity of rights and obligations. Without legal certainty people do not know what to do and will eventually cause unrest.

2. In addition to the need for legal certainty, the community also expects the benefits in the implementation of law enforcement, not to "law enforcement" actually cause public unrest, because if we talk about the law in general we only look to legislation that can be imperfect and Not aspirational to people's lives. It is unlikely that laws can regulate all aspects of human life perfectly, in addition to the substantial incompleteness of a law, there are also times when the law is unclear, in spite of the authoritarian power of political power which enacts laws made in accordance with legislation procedures, But does not reflect its usefulness to the community. The law is often cruel when it is strictly enforced: lex dura, sed tamen scripta (the law is cruel, but it does so).

In essence the purpose in implementing law enforcement is to demand justice. Law enforcement should be fair without discriminating between social status, class, ethnic or religious. Law enforcement should not be discriminated against. In the Constitution under Article 28i (2) of the 1945 Constitution states "Everyone has the right to be free from discriminatory treatment on any basis and entitled to protection against discriminatory treatment:" Talking about the issue of justice is not easy because justice is subjective and can be individualistic Can be generalized, because fair for A is not necessarily felt fair for B. Even if justice is difficult to formulate concretely, but individually can be felt according to conscience. To discuss a more comprehensive formulation of justice, it would be more objective when done with a philosophical approach ${ }^{13}$.

In relation to the extent to which the limits of the authority of advocates as law enforcement equal to state officials of the same status are not explained by the Advocate Law. The question is what is the definition of "equalization" as referred to in the Elucidation of Article 5 paragraph (1) of the Advocate Law. Former Chief Justice of the Constitutional Court Akil Mochtar questioned whether the meaning of "law enforcers" for Advocates is the same as law enforcers for Police, Prosecutors and Judges. ${ }^{14}$ The problem with the number of "Advocate Organizations" which play a "sole container" amounts to more than one although by the Constitutional Court in Decision Case No. 014 / PUU-IV / 2006 it was decided that the "Advocate Organization" referred to in the Advocate Law is PERADI so that without an institutional one, advocates cannot be granted status as "law enforcement". In the context of law enforcement and justice in which the Advocate profession should be an advocate of citizen

13 Gayus Lumbun, Bahan Ajar Sistem Peradilan Indonesia, Pendidikan Khusus Profesi Advokat (PKPA) Fakultas Hukum Universtas Diponegoro, Semarang, 2008, h. 20.

14 Pranoto Iskandar, Memahami Hukum di Indonesia, IMR Press, Cianjur, 2011, h. 166. 
defender, the advocate as a law enforcement advocates the independent Indonesian lawyer to change his status and assume the obligation to become a defender of the public interest or public defender. At this point, in the expert's opinion, the glory of the Indonesian Advocate profession is maintained in such a way by the professional organizations of Advocates; Which only serves as a guardian of the public interest. Such a condition in the perspective of the theory of dignified justice becomes lame. Any disparity in the relationship between individuals and society and individuals in society with the State is a form of injustice or injustice, and moreover, in the perspective of the theory of dignified justice means a humiliation of human dignity.

Soerjono Soekanto in the concept of factors affecting law enforcement suggests that, the principal issue of law enforcement actually lies in the factors that may affect it ${ }^{15}$.

Factors affecting law enforcement:

1. The legal factor itself, which in this article will be limited to the law only.

2. Law enforcement factors, namely the parties that make up and apply the law.

3. Factors of facilities or facilities that support law enforcement.

4. Community factor, ie environment in which the law is applicable or applied.

5. Cultural factors, namely as a result of work, inventiveness, and taste based on human initiative in the social life.

These five factors are closely related to each other and are the essence of law enforcement, also a benchmark of the effectiveness of law enforcement. Meanwhile law enforcement is related to some elements. The elements meant by Friedman are:

a). Legal substance;

b). The legal structure; and

c). Legal culture.

These three elements are often found in law enforcement within any legal system of any country. Such a view is a scientific view, because it contains a universal feature of enforceability, not only in one legal system but in all legal systems found in the world. That is, in the opinion of the researchers these three elements are always indispensable to be found in every law enforcement; Including law enforcement by Advocates.

The Advocate Profession is a noble profession (officium nobile). As a noble organization in upholding the law, an advocate in carrying out its duties and functions requires a code of ethics for justice to be enforced, and for the code to be exercised it is necessary to have a monitoring mechanism in the pofesi. The supervisory method of the advocate profession consists of internal control methods and external control methods. This supervision may also be referred to as a layered supervision method ${ }^{16}$.

\section{Internal Control of an Advocate According to Law no. 18 of 2003}

The internal supervisory mechanism against an advocate is mentioned in Law No.18 of 2003 on Advocates, ie supervision of advocates conducted by supervisory commissions and

15 Soerjono Soekanto, Faktor-faktor yang Mempengaruhi Penegakan Hukum, Raja Grafindo Persada, Jakarta, 2011, h. 8

16 Agus Raharjo dkk, Pengawasan Kinerja Advokat dalam Pemberian Bantuan dan Pelayanan Jasa Hukum, Jurnal Dinamika Hukum, 2006, h. 277. 
conducted daily by the Supervisory Commission established by the Advocate Organization. Regarding the supervisory committee, furthermore in the Code of ethics advocates referred to as the Honorary Board.

Supervision by the Council of Honor is a passive oversight, meaning that it is only done after a violation of the code of conduct occurs. This implicitly can be seen from the provisions of Chapter X on the Council of Honor. The Honorary Board is authorized to examine and adjudicate cases of violations of the Code of Conduct by Advocates. The sentence of examining and adjudicating the case clearly indicates that there must be a violation first. New offenses can be identified after complaints from interested parties and feel aggrieved, and complaints must be filed in writing. Parties who can complain are:

a. Client;

b. Friends of Advocates;

c. Government officials;

d. Community Members; And / or

e. Board of Directors of Central / Branch / Regional from professional organizations where collectively become members.

As mentioned earlier, supervision is only made after complaints from those concerned, so in carrying out the mandate of the Advocate Law and Code of Ethics, the Honor Board does the following:

a. No later than 14 days after the complaint is received by the honorary board, the honorary board shall submit a complaint letter to the complained advocate.

b. No later than 21 days after the complaint is received by the complainant, he is obliged to provide an answer. If within the specified time the counterpart does not provide an answer, the honorary council submits the second letter, and within 14 days there is no answer then the complainant is deemed to have immediately given the decision on the complaint.

For advocates who are proven to violate the code of ethics then the sanctions are:

a. The usual warning, when the nature of the offense is not heavy.

b. A strong warning, when the nature of the offense is severe or by repeating a violation of the code of ethics and or ignoring any warning sanctions given.

c. A temporary suspension for a certain period of time, when the nature of the offense is severe, does not respect and does not respect the provisions of the code of ethics or if after receiving sanctions in the form of a severe warning still repeated violations of the code of ethics.

d. Dismissal from membership of professional organization whenever a violation of the code of ethics with the intent and purpose of damaging the image and dignity of honor of the Advocate profession shall be respected as a noble and honorable profession.

\section{External Supervision of an Advocate According to Law No. 18 of 2003}

In Law Number 18 Year 2003 as well as in Advocate Code of Ethics there is no mention of the mechanism of external supervision. In the provision of Article 11 of the Advocate Code of Ethics concerning the Parties that may file a violation of the code of ethics, it may be 
concluded that those mentioned in this article are those who may exercise external control.

Act No. 18 of 2003 on Advocates states that PERADI organization is a single forum for advocates, but in its development in 2008 stands an advocate organization called Congress of Indonesian Advocates. In 2010 the two organizations have agreed to sign KAI's joining into a single container, but in practice fail to organize KAI's organization and organize a demonstration to the Supreme Court several times so that its members can be sworn in front of the Chief Justice. In relation to the demos, the Supreme Court is of the opinion that PERADI is the sole organization of the Advocate organization. In the year 2015 held MUNAS PERADI in Makassar, but failed that eventually PERADI broke into 3 (three) organizations so that out Circular Letter Supreme Court. 73 KMA / HK.01 / IX / 2015 whose contents are among others that organizations that can file an oath are not only PERADI but other Advocate organizations.

In connection with the issuance of Circular Letter of the Supreme Court. 73 KMA/ HK.01 / IX 12015, then the original single bar (PERADI) became a multi-bar (many organizations) recognized. The issue that arises is an Advocate who is sanctioned by the Advocate Honorary Board may move to another organization and may re-engage. Based on the facts that have been described by the researcher above, then there is now a legal vacuum in advocate organization, that is Law no. 18 of 2003 on Advocates has been disobeyed by the Advocates themselves.

Based on the research with the normative approach, the researcher believes that if the advocate punishment imposed by the Council of Honor in the form of:

1. Strikes up to suspension, then the implementation:
a. Submitted to each organization
b. The nature of the verdict is final
c. Verdict with a copy of all advocate organizations

2. For dismissal, then the implementation:

a. Can be disconnected by each organization

b. May appeal to the Central Honorary Board (single container) and be final

c. Result of verdict with copy to all advocate organizations, to the Chief Justice of the Supreme Court and published to print and electronic media.

The purpose of supervision is intended to advocate organizations participate in monitoring as well as the community is included. Therefore, the implementation of the Honorary Council's decision on advocates subject to sanctions to date has not been implemented, especially for advocates who are subject to permanent dismissal sanctions and not yet in accordance with law enforcement theory. According to the law enforcement theory of Gayus Lumbun stating that "In enforcing the law there can be a dilemma that clashes with the following three elements, where if certainty is given priority, then other elements will be sacrificed, so if the elements of benefit are noticed, then the legal certainty and justice Sacrificed. In law enforcement there must be a compromise between the three elements that must be proportionally balanced."17

In upholding the law to achieve the order of society contained three elements that must always be considered, namely legal certainty (rechtszekerheid), usefulness (nuttigheid) and justice (rechtsvaardigheid).

17 Gayus Lumbun, Op. Cit., h. 21. 
1. Legal certainty is a yustisiable protection against the arbitrary acts of law enforcement officers or any party, because with the certainty of public law will be orderly and guarantee clarity of rights and obligations. Without legal certainty people do not know what to do and will eventually cause unrest.

2. In addition to the need for legal certainty, the community also expects the benefits in the implementation of law enforcement, not to "law enforcement" actually cause public unrest, because if we talk about the law in general we only look to legislation that can be imperfect and Not aspirational to people's lives. It is unlikely that the law can regulate all aspects of human life perfectly, in spite of the substantial incompleteness of a law, there are also times when the law is unclear, in addition to the political will of authoritarian power which enacts laws made in accordance with the procedure Legislation, but does not reflect its usefulness to the community, however, any applicable law must be implemented. The law often feels cruel if it is strictly enforced: lex dura, sed tamen scripta (the law is cruel, but it does so)

3. In essence the purpose in carrying out law enforcement asdalah demanding justice. Law enforcement should be fair without discriminating between social status, class, ethnic or religious. Law enforcement should not be discriminated against. In the Constitution under Article 28i (2) of the 1945 Constitution states "Every person shall have the right to be free from discriminatory treatment on any basis and shall be entitled to the protection of such discriminatory treatment." Talking about the issue of justice is not easy because justice is subjective and can be individualistic that cannot be generalized, because fair for A is not necessarily felt fair for B. Although justice is difficult to formulate concretely, but individually can be felt according to conscience. To discuss a more comprehensive justice formula would be more objective when done with a philosophical approach. ${ }^{18}$

\section{CONCLUSION}

Advocates as noble professions must uphold the laws and regulations of the code of ethics, so that if a violation is detrimental to the profession or the client should get the action in the form of sanctions imposed also did not eliminate the right to continue running the profession. This is where the dignity of an advocate remains respected while sanctions are a form of repression for the offenses committed. A single container that is legally recognized by all advocate organizations is required for advocates in carrying out their profession as law enforcement. This single advocate container is authorized to supervise the advocate.

\section{REFERENCES}

A. Rahmat Rosyadi, dan Hartini Sri, 2003, Advokat Dalam Perspektif Islam dan Hukum Positif, Ghalia Indonesia, Jakarta.

Abdulkadir Muhammad, 2006, Etika Profesi Hukum, Cet. III, Citra Aditya Bakti, Bandung.

Agus Raharjo, dkk, Pengawasan Kinerja Advokat dalam Pemberian Bantuan dan Pelayanan Jasa Hukum, Jurnal Dinamika Hukum.

Ahmad Amin, 1995, Etika (Ilmu Akhlak), Bulan Bintang, Jakarta.

Artijo Alkostar, 2010. Peran dan Tantangan Advokat dalam Era Globalisasi, UII Press, Yogyakarta.

18 Gayus Lumbun, Op. Cit., h. 19-21. 
C.S.T. Kansil, 2003, Pokok-pokokEtika Profesi Hukum, Pradnya Paramita, Jakarta.

Dellyana, Shant, 1988, Konsep Penegakan Hukum, Liberty, Yogyakarta.

Frans Hendra Winata, 1995. Advokat Indonesia, Citra, Idealisme dan Kepribadian, Sinar Harapan, Jakarta.

Gayus Lumbun, 2008, Bahan Ajar Sistem Peradilan Indonesia, Pendidikan Khusus Profesi Advokat (PKPA) Fakultas Hukum Universtas Diponegoro, Semarang.

Harjono, Perlindungan Hukum (Membangun sebuah Konsep Hukum), Makalah tidak diterbitkan, Fakultas Hukum Univesritas Airlangga, Surabaya.

Ishaq, 2012, Pendidikan Keadvokatan, Sinar Grafika, Jakarta.

J.H. Rapar, 2001. Filsafat Politik: Plato, Aristoteles, Augustinus, Machiavelli, Raja Grafindo Persada, Jakarta.

J.P. Fitzgeral, Salmon on Jurprudence, Sweet and Maswel, London, 1966. Dikutip dari Satjipto Rahardjo, Ilmu Hukum, Citra Aditya Bakti, Bandung, 2000,

Jazim Hamidi, 2005, Makna dan Kedudukan Hukum Naskah Proklamasi 17 Agustus 1945 dalam Sistem Ketatanegaraan Republik Indonesia, Disertasi, Program Pascasarjana Universitas Padjadjaran, Bandung

Karl H. Peschke, 1994. Christian Ethics. Moral Theology in the Light of Vatican II Manila: Divine Word Publications.

Lasdin Wlas, Wlas, Lasdin, 1989, Cakrawala Advokat Indonesia, Liberty Yogyakarta.

Luhut M.P. Pangaribuan, 2013, Hukum Acara Pidana; Surat Resmi Advokat di Pengadilan, Papas Sinar Sinanti, Jakarta.

M. Yusuf Hanafiah dan Amri Amir, 1999, Etika Kedokteran dan Hukum Kesehatan, E.G.C, Jakarta.

Munir Fuady, 2005, Profesi Mulia (Etika Profesi Hukum bagi Hakim, Jaksa, advokat, Notaris, Kurator, dan Pengurus), PT. Citra Aditya Bakti, Bandung.

Mukti Arto, 2001, Mencari Keadilan (Kritik Solusi terhadap Praktik Peradilan Perdata di Indonesia), Pustaka Pelajar, Yogyakarta.

Oemar Seno Adji, 1991, Etika Profesional dalam Hukum, Profesi Advokat, Penerbit Erlangga, Jakarta.

Philipus M. Hardjon, 1987. Perlindungan Hukum Bagi Rakyat Indonesia (Studi tentang Prinsip-prinsipnya, Penanganannya oleh Peradlian Umum dan Pembentukan Peradilan Administrasi Negara,: Bina Ilmu, Surabaya.

Peter Mahmud Marzuki, 2006. Penelitian Hukum, Kencana Prenada Media Group, Jakarta.

Pranoto Iskandar, 2011. Memahami Hukum di Indonesia, IMR Press, Cianjur.

Rapaun Rambe, 2003, Teknik Praktek Advokat, Grasindo, Jakarta.

Ridwan Widyadharma, 2006, Etika Profesi Hukum, Badan Penerbit Universitas Diponegoro, Semarang.

Rusli Muhammad, 2012, Lembaga Pengadilan Indonesia Beserta Keputusan Kontroversial, UII Yogyakarta Press, Yogyakarta. 
Sartono dan Bhektin Suryani, 2013, Prinsip-prinsip Dasar Frofesi Advokat, Dunia Cerdas, Jakarta.

Shidarta, 2006, Moralitas Profesi Hukum, Suatu Tawaran Kerangka Berpikir, Refika Aditama, Bandung.

Sidik Sunaryo, 2004, Kapita Selekta Sistem Peradilan Pidana, Penerbitan Universitas Muhammadiyah Malang, Malang.

Sir John William Salmond, 1966. Jurisprudence, (ed), P. J. Frizgerald, Sweet and Maxwell, London.

Soerjono Soekanto, 2011, Faktor-faktor yang Mempengaruhi Penegakan Hukum, Raja Grafindo Persada, Jakarta.

2004, Faktor-faktor yang Mempengaruhi Penegakan Hukum, Cetakan Kelima, Raja Grafindo Persada, Jakarta.

Soerjono Soekanto, 1985, Efektivitas Hukum dan Peranan Sanksi, Remaja Rosda Karya, Bandung.

Sudikno Mertokusumo, 2005, Mengenal Hukum: Suatu Pengantar, Liberty Yogyakarta, Yogyakarta.

1991, Mengenal Hukum (Suatu Pengantar), Liberty, Yogyakarta.

Syprianus Aristeus, 2007, Penelitian Hukum tentang Perbandingan Antara Penyelesaian Putusan Praperadilan dengan Kehadiran Hakim Komisaris Dalam Peradilan Pidana, Badan Pembinaan Hukum Nasional Departemen Hukum dan Hak Asasi Manusia RI, Jakarta.

Teguh Prasetyo, 2007, Keadilan Bermartabat, Perspektif Teori Hukum, Cetakan Pertama Nusan Media, Bandung.

Teguh Prasetyo dan Abdul Halim B., 2012, Ilmu Hukum dan Filsafat Hukum (Pemikiran Menuju Masyarakat yang Berkeadilan dan Bermartabat), Raja Grafindo Persada, Jakarta..

Todung Mulya Lubis, 2005, Jalan Panjang Hak Asasi Manusia, Gramedia Pustaka Utama, Jakarta.

Tolib Effendi, 2013, Sistem Peradilan Pidana; Perbandingan Komponen dan Proses Sistem Peradilan Pidana di Beberapa Negara, Pustaka Yustisia, Yogyakarta.

V. Harlen Sinaga, 2011, Dasar-dasar Profesi Advokat, Erlangga, Jakarta.

Yoe Tjeh Kie, 1993, Malpraktik Advokat dan Sanksi Kode Etiknya, Universitas Indonesia, Jakarta.

\section{Internet, Jurnal, Synopsis, dan Koran :}

Code of Law dalam Hukum Law Review, Fakullas Hukum Universtas Pelita Harapan, Vol. IV No. I, Juli 20047 Lumhuun: Peran Advokat sebagai Penegak Hukum Menghadapi Transnational Positif yang juga Mengikat Publik.

Law Review, Fakultas Hukum Uttiven Advokat sebagai penegak hukum berdasarkan UndangUndang Nomor 18 Tahun 2003 tentang Advokat, Peran Advokat haruslah tidak menjadi BadMan. 
Pengacara Anggodo Halangi KPK, http://bataviase.co.id/node/208201

http://hamyangberlakuumum/global/pelajaranilmuppkn/pmpindonesia/htp.Godam64, Pengertian Macam Dan Jenis Hak Asas Imanusia.

http://makalahdanskripsi.blogspot.com/2009/01/organisasi-manajemen.html oleh Caray, Organisasi Manajemen.

http://massofa.wordpress.com/2008/02/05/pengertian-fungsi-dan-jenis-pajak/karya Sapri Nurmantu, Dasar-dasar Perpajakan.

http://www.blogster.com/khaerulhtanjung/sejarah-hukum-advokat-indonesia

http://www.hukumonline.com. Pusat Data Hukumonline.

www.komisihukum.go.id. Hendra Winarta, Frans, Dimensi Moral Profesi Advokat dan Pekerja Bantuan Hukum, 14 Juni 2006., Dimensi Moral Profesi Advokat dan Pekerja Bantuan Hukum, 14 Juni 2006.

www.komisihukum.go.id/article_opinion.php. 